Ponto de Vista 
Um espaço destinado ao patrocinador para colocar em debate idéias e ações relacionados aos temas de interesse do IEA. 


\section{A reforma do Sistema Financeiro Nacional}

\section{ALDO LUIZ MENDES}

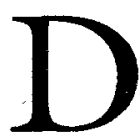

iscute-se hoje no país a reforma do Sistema Financeiro Nacional. Uma norma complementar à Constituição deverá substituir a Lei 4.595, de 31/12/64, o mais importante normativo da reforma financeira que criou o Conselho Monetário Nacional (CMN) e o Banco Central do Brasil. Ao CMN foi delegada a formulaçáo geral das políticas monetária e creditícia, cabendo ao Banco Central executá-las.

Ainda como parte integrante da reforma implementada a partir de 1965 , foram criados os bancos de investimento, que deveriam operar no segmento de empréstimos de médio e longo prazos. Porém, na prática, essas instituições não alcançaram tal intento, tendo a oferta de crédito de longo prazo ficado restrita aos organismos oficiais.

A estrutura institucional do sistema financeiro então montada, perdurou até 1988. Ao longo desse período, assistiu-se a um intenso processo de concentração no setor. Estimulados pela política governamental então vigente, seis bancos de maior porte passaram a adquirir o controle daqueles de menor capacidade econômico-financeira e muitas instituiçóes consideradas grandes fundiram-se para formar poderosas estruturas empresariais. E curioso notar que, embora a reforma de 1964-65 tenha estabelecido as normas para o surgimento de instituiçóes estanques e especializadas, operando em ramos diferentes da atividade financeira, o que ocorreu efetivamente foi a diversificaçáo do leque de produtos dos bancos comerciais já existentes.

Em 1988, por resolução do Conselho Monetário Nacional, foi criada a figura dos bancos múltiplos. A partir daí, aquelas instituiçóes que assim o desejassem poderiam reunir as várias empresas de um conglomerado financeiro numa única pessoa jurídica. Essa alteraçâo, que marca um movimento inverso ao da reforma dos anos 60 , foi importante para alterar a forma de organizaçáo das instituiçōes, embora tenha sido pequeno o impacto sobre sua maneira de atuar porque, na verdade, já operavam como autênticos bancos múltiplos.

O Sistema Financeiro Nacional possibilitou a geração de créditos internos em escala significativa ao longo dos períodos em que o ciclo 
econômico se mostrou ascendente. Por exemplo, durante o "milagre econômico", de 1966 a 1974, os empréstimos ao setor privado evoluíram mais de $600 \%$ em termos reais. No entanto, foi a entrada líquida de capitais externos até 1981, via empréstimos em moeda, a principal modalidade de financiamento de longo prazo encontrada pela economia brasileira. Nos anos 70, a entrada de recursos externos através da Lei 4.131 (captação direta no exterior) e da Resolução 63 (captaçáo externa através da intermediação de um banco brasileiro) foi, em média, equivalente a duas vezes o total dos créditos gerados a partir de fontes internas tradicionais de financiamentos de longo prazo.

Como o endividamento proporcionou ao país uma situação de liquidez extremamente folgada, nos anos 70 , a poupança doméstica pôde ser direcionada para o financiamento do capital de giro das empresas. Já o atendimento da demanda de crédito para investimento foi transferido ao setor externo e, subsidiariamente, aos organismos oficiais internos de financiamento.

A partir dos anos 80 , com o estrangulamento de natureza externa e a inflexão do ciclo econômico, o crédito doméstico ao setor produtivo contraiu-se drasticamente. O montante das operaçōes registradas ao final de 1980 representava apenas a metade, em termos reais, do nível alcançado em 1978. Enquanto isso, pelo lado dos haveres financeiros em circulação na economia, observava-se um significativo incremento da emissão de títulos governamentais.

$\mathrm{Na}$ última década, o sistema financeiro, atado às necessidades crescentes de recursos para lastrear a dívida pública interna governamental, vivenciou um processo de sofisticação e, ao mesmo tempo, de descaracterização de suas principais funçóes. Ele deixou de intermediar recursos para as esferas produtivas e transformou-se no principal instrumento de rolagem da dívida mobiliária estatal. Na competição pelos fundos disponíveis na economia, as instituiçōes lançaram-se em pesados programas de informatização de seus serviços, visando diversificar atividades e prestar melhores serviços a seus clientes.

Se os bancos deixaram de ser atraídos pelas aplicaçóes de recursos nas esferas produtivas, ofertando menos recursos ao financiamento das atividades do setor privado, não é menos verdade que o próprio setor produtivo da economia passou a demandar menos crédito. As políticas de ajustamento econômico de cunho ortodoxo e as incertezas com relação ao futuro deprimiram o investimento, levando empresas e rentistas a preferirem $o$ abrigo seguro das letras do Tesouro ao invés de correrem os riscos e as vicissitudes inerentes ao investimento produtivo. 
Portanto, pode-se dizer que, com o estrangulamento externo e as suas conseqüências sobre as contas do setor público brasileiro, os bancos se tornaram os grandes canalizadores de recursos para a rolagem do endividamento interno governamental. Por outro lado, o tipo de tentativa de ajustamento, em linhas ortodoxas, que prevaleceu na maior parte do período posterior a 1982 , reduziu drasticamente a demanda interna por investimentos.

Assim, a ciranda financeira que se estabeleceu com os papéis do Tesouro acabou sendo um mecanismo funcional para o governo, as instituiçōes financeiras e o próprio setor produtivo privado. Isso porque: o primeiro rolava seus débitos; o segundo fugia do risco privado, crescente num momento de recessão, para o risco "soberano", representado pelas obrigaçóes do Tesouro; e o setor produtivo encontrava na ciranda financeira não só uma forma de tentar preservar o valor real de sua riqueza líquida, como também uma alternativa de aplicaçáo de seus ganhos e lucros, dada a impossibilidade de transformá-los em novas inversōes produtivas num quadro de recessão, queda dos rendimentos reais dos assalariados e redução do emprego, prevalecentes no país há mais de uma década.

Em síntese, na ciranda financeira articularam-se a necessidade do governo em girar seu endividamento com a preferência pela liquidez do setor produtivo que, assombrado com o estado das expectativas, deixou de investir.

O endividamento do setor público - embalado primeiramente pela contratação de empréstimos externos e depois pela política de endividamento interno - foi sensivelmente afetado pela manutenção de altos patamares de juros nos mercados internacional e doméstico, o que acabou proporcionando às empresas do setor privado, credoras da dívida pública mobiliária, uma fonte atraente de aplicaçáo de recursos frente ao quadro recessivo interno e à degeneraçáo das expectativas de longo prazo.

Foi nesse quadro que o desenvolvimento do sistema financeiro caminhou "pari passu" com o movimento de especulação baseado nos títulos públicos, no qual as instituiçōes financeiras deixaram de cumprir seu papel de indutoras do investimento e passaram a operar como canalizadoras de recursos para a rolagem da dívida mobiliária do Estado.

\section{Algumas diretrizes para a reforma do Sistema Financeiro}

No momento de se elaborar a nova lei do SFN é importante que 
se tenha em mente esse quadro, para que o normativo a ser apresentado possa proporcionar ao país um sistema financeiro eficaz, livre das disfunçóes hoje apresentadas e comprometido efetivamente com o apoio à produçáo. Claro deve estar, entretanto, que a lei, embora condição necessária, não será suficiente para modificar significativamente a situaçăo atual. A volta das operaçóes de crédito como instrumento de alavancagem do desenvolvimento econômico só ocorrerá após a estabilização da moeda e a mudança do perfil da dívida pública.

Como as condiçóes da economia brasileira na última década não têm favorecido o surgimento de linhas de crédito espontâneas para os segmentos mais débeis do sistema econômico, tais como as pequenas e médias empresas e o setor rural, ou para aqueles segmentos que demandam financiamentos de longo prazo, a importância e a responsabilidade das instituiçóes oficiais tornaram-se ainda maiores, já que năo se pode contar com o crédito privado para o estímulo de setores táo relevantes.

O retrospecto das últimas décadas mostra que os bancos oficiais federais têm sido praticamente a única fonte doméstica de recurssos de longo prazo, destacando-se o BNDES, no financiamento da indústria e da infra-estrutura básica, e o Banco do Brasil, no fomento do setor rural, nas exportaçóes e no apoio às pequenas empresas.

Outra funçáo que os bancos oficiais voltaram recentemente a desempenhar é a captação de recursos externos, marcando a volta do Brasil ao mercado internacional de capitais autônomos, desvinculados dos acordos de negociaçáo da dívida externa.

Atualmente, as taxas de juros prevalecentes no mercado internacional, comparativamente à situação doméstica, tornaram o crédito externo mais interessante para as empresas nacionais. Contudo, dado o grau de risco associado ao Brasil, em virtude de seu passivo externo, a tarefa de colocação de bônus brasileiros no mercado internacional requer a interveniência de instituiçóes de porte, tradição e solidez, que possam minimizar o risco Brasil.

O Banco do Brasil, em particular, tem obtido sucesso em tal objetivo. Já colocou no mercado internacional, desde janeiro de 1992, US\$ 300 milhōes em títulos de sua própria emissão, além de ter operado como líder ou co-líder em outras iniciativas que representaram mais de US\$ 2 bilhóes em bônus de empresas nacionais.

Então, uma vez evidenciada a importância das instituiçóes financeiras oficiais, torna-se necessário ter-se o cuidado de não as deixar à margem da regulamentação do Sistema Financeiro Nacional como, a 
princípio, parece ocorrer em alguns projetos de lei que ora tramitam no Congresso. A esse respeito, a Carta Magna de 1988 é explícita ao afirmar que o normativo disporá sobre a organizaçáo, as atribuiçóes e o funcionamento do Banco Central e das demais instituiçóes financeiras, inclusive as públicas.

Não só as funçōes, forma de organização e atribuiçōes das instituiçóes oficiais devem estar explicitadas na lei, como também deve ser a elas permitido o acesso a todos os segmentos do mercado financeiro. No novo tempo que se avizinha náo haverá espaço para os bancos que vivam de favores cartoriais. Será preciso, primordialmente, buscar eficiência e qualidade, e não há como fazê-lo em desigualdade de condiçóes com a concorrência.

Um ramo que os bancos oficiais poderiam ajudar a desenvolver no país diz respeito aos fundos de previdência complementar. Instituiçóes centenárias como o Banco do Brasil sáo candidatos naturais a receber a preferência do público no momento em que o trabalhador tiver de escolher a quem confiar sua poupança pelo prazo de até $\mathbf{3 0}$ anos. Paralelamente, tais recursos, exigiveis a longo prazo, compóem um excelente funding para lastrear operaçóes de fomento econômico a longo prazo.

Outra questăo que vem à tona na discussão da regulamentação do SFN está relacionada com o grau de independência que se queira dar ao Banco Central. É importante, sem dúvida, que a Autoridade Monetária tenha autonomia suficiente para gerir a política monetária. Deve-se ponderar, contudo, que ao se concederem mandatos a sua diretoria com prazos descasados do mandado do chefe do Executivo e ao se impossibilitar o afastamento de qualquer membro de sua diretoria pelo presidente da República, pode-se estar caminhando não só para conflitos institucionais sérios, entre os entes do Estado, como também para o perigoso extremo de transformar a Autarquia num órgáo descompromissado dos planos e das açóes de governos eleitos democraticamente.

Seria oportuno ainda lembrar que a independência do Banco Central náo deve ser encarada como uma panacéia. Causas múltiplas estão na raiz da inflação brasileira e o fenômeno monetário é apenas mais uma delas. Sem o enfrentamento da questáo fiscal e sem o estabelecimento de uma política de rendas que possa minimizar tanto o componente inercial quanto o de expectativas inflacionárias, qualquer tentativa de se conceder plena independência ao Banco Central estaria fadada ao fracasso.

De tudo isso, pode-se depreender que a crise econômica que se 
abate sobre o Brasil, sobretudo a partir do estrangulamento externo do início da década passada, levou o sistema financeiro à posiçăo de agente eminentemente captador de recursos de curto prazo, carreados, em sua maioria, para a rolagem da dívida pública mobiliária. $O$ Parlamento, $o$ governo e os setores responsáveis da sociedade brasileira devem ter esse quadro como referencial, para buscar fórmulas que possam dotar o Sistema Financeiro Nacional, a médio prazo, do arcabouço necessário à retomada de suas funçóes clássicas de intermediador de recursos e indutor do desenvolvimento. Contudo, como é sabido, a legislação, sozinha, náo será capaz de criar tais condiçóes, sendo indispensável que, antes, se adotem medidas para estabilizar a moeda e reequacionar a forma de rolagem da dívida mobiliária interna, tarefas que pressupóem o reordenamento das finanças públicas.

Aldo Luiz Mendes, economista, é vice-presidente do Conselho Regional de Economia do Distrito Federal. 